\title{
Global English: Africanization of the English Language
}

\author{
Irina Nickolaevna Khokhlova ${ }^{1}$ \\ ${ }^{1}$ Vitus Bering Kamchatka State University, Petropavlovsk-Kamchatskiy, Russia \\ Correspondence: Irina Nickolaevna Khokhlova, Pogranichnaya Street, 4, Petropavlovsk-Kamchatskiy, 683032, \\ Russian Federation. Tel: 7-962-280-2391. E-mail: irisha.n.56@mail.ru
}

Received: February 28, 2015 Accepted: March 20, 2015 Online Published: April 24, 2015

doi:10.5539/res.v7n6p201

URL: http://dx.doi.org/10.5539/res.v7n6p201

\begin{abstract}
The process of globalization in modern world has affected all spheres of our life-politics, economy and culture. To realize these processes people should have a common means of communication-a lingua franca. The English language has become this lingua franca, as about 1.5 billion people speak English today. This article deals with the problem of the English language africanization, regarding the position of English in South Africa and other languages impact on South African English development, Dutch, Afrikaans and especially native African languages.
\end{abstract}

Keywords: cross-cultural communication, South African English, varieties, africanisms

\section{Introduction}

Africa is considered today to be perhaps the most multilingual region in the world, with more languages spoken per capita than anywhere else. It is estimated that 1,000 to 1,140 languages are spoken in Africa today (Khokhlova, 2007). Except in a very few cases, African nations are multilingual; the typical country lacks both an indigenous nationwide language of communication and a language policy that proposes the development and implementation of such a language. This situation has facilitated the penetration and entrenchment of the former colonial languages (i.e. English, French, and Portuguese) as the official media of communication for administration, education, commerce, and diplomacy in African states. As is to be expected in such a multilingual situation, the interaction of the three European languages with African languages has produced very interesting sociolinguistic phenomena, e.g., code-switching and code-mixing, structural changes in the European and African languages involved, and continued debates on the africanization of education and the language of instruction.

The phenomena of code-switching and code-mixing in English have been discussed at some length in the literature (Abdulaziz et al., 1972). Much attention has recently been devoted and will be devoted to the problem of language policies in African education (Ansre, 1975; Bamgbose et al., 1976). Very little attention, however, has been given to the study of African languages influence on European languages in general, and on English in particular. The reverse situation, the influence of English, French, and Portuguese on African languages, has remained almost completely neglected. These are areas of great sociolinguistic interest that might be pursued simultaneously with promising theoretical and practical results.

South Africa re-entered the world community in 1994 after several decades of apartheid and consequent international censure. According to the constitution the South African Republic has eleven official languages - two European in origin, and nine belonging to the Bantu family of languages (South African language policy, 2010). Each of these eleven languages enjoyed some level of "official" status in South Africa under apartheid-English and Afrikaans in what was sometimes known as "white" South Africa, and each African language in its ethnic "homeland" or "national state" areas of South Africa declared independent by the National Party government with the goal of accommodating the political aspirations of black South Africans. While three quarters of South Africa's population speak one of the Bantu languages as their first language, only 15 per cent speak Afrikaans as first language, and just over 9 per cent are English-speaking (Penny, 1996). In addition to the communities speaking the eleven official languages, there are smaller groups speaking Portuguese, German, Greek, but though the "Bushman" languages are not recognized as "official" languages, they are guaranteed protection as community languages in the constitution. 


\section{Method}

The present paper falls into a larger study of English regional and social dialectology in post-apartheid South Africa, with an especial interest on the changing norms of people in a desegregating society. There is no vast foundation for dialectology and variationist studies in South Africa. The most important work is the short monograph of Mesthrie (1992), which provided a socio-historical theory of English-speaking society in South Africa. It is time now to return to dialectology and variationism, with a prime focus on the anthropocentric approach to the English language development in South Africa. Matters pertaining to language variation have become a matter of public curiosity, as identities and accents become more fluid in a deracialising climate. Whereas African languages are still in robust health, there is a trend toward what might be called "Afro-multilingualism", in which English has become an important part of the repertoire of an increasing number of urban speakers. Talk of language shift, however, is premature, except for the new middle class of Black South Africans. It is this variety and its dynamics that will be explored in this paper.

Data material in the present study comes from South African dictionaries, South African fiction published in English, newspapers, radio, TV programs of South African Republic and native speakers provided by the Embassy of South African Republic in Moscow. The main aim of the study is to show how South African variety of the English language originated, developed and what languages were the most influential on South African English formation.

Text categories were assumed to correlate with increasing degrees of formality of the speech situation, with conversations being the least and news being the most formal speech setting. Radio hosts and their interview partners are the participants in broadcast programs featuring discussions between figures of public interest such as government officials, politicians, businessmen, lawyers, etc. moderated by the radio hosts, radio newscasts, composed of previously written and sometimes rather formulaic texts read out by professional speakers and directed at the general public over the radio, were included as the most formal text category.

\section{Results}

\subsection{The Role of English in South Africa}

Despite the small number of native English speakers (about 3 million), English is disproportionately influential, being used by many millions of speakers as lingua franca, as a second or third language. There is thus a wide range of levels of competence in the language, from native English-speakers on the one hand to those who use the most elementary English as a communication tool on the other. The position of English as an international language, its adoption by the liberation movements, its widespread use in commerce and industry, and the almost exclusively Afrikaans character of government, police, and civil service during the apartheid era are all factors which have led to the perception among many black South Africans that acquiring competence in English is highly desirable. The effects of apartheid - the separation of communities into socially distinct groups, and the powerful consciousness of ethnic divergence which developed, affected all aspects of life, including language (Khokhlova, 2011). White, Black, Coloured, and Indian South Africans use English, with varying degrees of sophistication, but as a result of their isolation from one another, native English, Afrikaans English, Black English, Coloured English, and Indian English are distinguishable from one another, each containing lexical items unknown to people of other groups, and each containing lexical items unknown to people of other groups, and each exhibiting characteristic pronunciations and even grammatical structures. Despite the powerful position of English as lingua franca, particularly since 1994 multilingualism is increasingly supported by government in an attempt to safeguard the rights of all language communities. The development and promotion of the African languages, ignored in the past, is an important component of multilingualism (Gough, 1996).

\subsection{English and South African Dutch}

English first came to South Africa at the end of the 18th century during the first British occupation of the Cape (1795-1803). In 1795 the first British administration at the Cape inherited Dutch laws, bureaucracy, currency, and weights and measures. The Cape was at first perceived by the British government as a strategic possession rather than as a colony, and the small new community of English-speakers consisted mainly of administrators, soldiers, and merchants. The advent of English marked the beginning of struggle for supremacy with South African Dutch (later Afrikaans) which would last for almost two centuries. The African languages were not perceived as relevant to the issue of language stronghold and power. From the second decade of the 19th century English gradually began to dominate as the language of official and commercial interaction at the Cape. In 1827 the Dutch legal system of landdrost and heemraden was replaced by resident magistrates and civil commissioners, and English became the medium of the courts (with interpreting available). This caused particular resentment in the rural areas, where South African Dutch was the lingua franca. English was afforded 
special protection under the Cape constitution of 1853. In the mid-1870s an Afrikaner political and cultural revival included the promotion of the Afrikaans language. Afrikaners struggled to have Dutch accepted as a medium of instruction in the Cape schools together with English. In the 1880s in the Transvaal Republic, a similar struggle was waged on behalf of English by the uitlander (foreign) population. The South African War of 1899-1902 saw relations between English-speakers and Afrikaners at their lowest ebb. After the Boers' defeat the Transvaal was granted responsible government, but the official language was to be English. The attempt at establishing English in South Africa at the cost of Afrikaans led to bitter resentment among Afrikaners towards all things English (Walker, 1972).

The constitution of the Union of South Africa (1910) declared English and Dutch as the two official languages, Afrikaans being added in 1925. After 1948, when the National Party came to power, despite the legal position of English as the second official language, Afrikaans was afforded favorable status, and was used as the language of government and the civil service, and was promoted as a medium of instruction in black schools. However, once talks had been initiated between the National Party and the resistance movements in 1992, English was the language used during the resulting negotiations. Since the election of 1994 and the advent of the African National Congress-dominated Government of National Unity, there has been a noticeable shift to English as the language of government.

\section{3 $19^{\text {th }}$ Century English-Speaking Immigrants}

English became an established South African language only after the arrival in 1820 of 4,000 British immigrants. This organized and subsidized immigration resulted in the first sizeable English-speaking community in South Africa's history to interact with neighbours from other language communities, and to be committed to remaining in their new environment. They were a diverse collection of people, separated by regional dialect, class accent, and widely differing educational and economic backgrounds. However, the hardships of the South African frontier environment - war, drought, floods, and crop diseases — united the settlers into a group with a common experience and common troubles. This resulted in the emergence of a generation which, having been raised on the frontier, had their own regional dialects and accents of a new Eastern Cape English, with its distinctive pronunciation and vocabulary. English has always changed and grown through its ability to absorb new words, and settlers English was no exception. It soon included words borrowed from the languages and cultures among which the new immigrants lived. As their life changed, so did their vocabulary.

Other organized immigrations of English-speaking settlers followed that of 1820; then came the discovery of diamonds (1867) and the opening of the Witwatersrand gold fields (1886), the rapid growth of an uitlander (foreign) population in the Transvaal Republic, and the development of an industrialized society. The diamondand gold-fields spawned a new technical and informal vocabulary, including banket (gold-bearing conglomerate), blueground (diamond-bearing ground), bossboy (a black team-leade'), compound (labourers' living-quarters), fancy (coloured diamond), kopje-walloper (a diamond-buyer), melee (small diamonds), mine captain (the overseer of an area of a mine), mine-dump, onsetter (one responsible for controlling the lift in the shaft, probably from the Afrikaans aansitter), and shiftboss (Penny, 1996).

\subsection{South African Dutch and Afrikaans}

Of all South Africa's languages South African Dutch (later Afrikaans) has had the greatest effect upon the vocabulary of South African English (SAE). The first contact between British and Dutch at the Cape of Good Hope in the late 18th and early 19th centuries resulted in English accounts of Cape life in which Dutch words were included to add colour. The Dutch words which appeared in English between 1795 and 1820 reflect the transfer of administrative power from one culture to another: terms such as aum (a unit of liquid measurement), baaken (a post for marking boundaries or claiming territory), Burgher Senate, drostdy (a magisterial district), erf (a plot of residential land), field- (or veld-) cornet (an administrative official), fiscal (the chief legal officer at the Cape), heemraad (a member of a court of local officials assisting the magistrate), Jan Compagnie or John Company (nicknames for the Dutch East India Company), landdrost (a magistrate), morgen (a unit of land measurement), placaat (an official notice), opgaaf (a tax-return), and rixdollar and stiver (units of currency) are common in English writing of the period. Most of these words are historical curiosities, recording the vocabulary of a former time; however, words reflecting the daily life of the Cape people, and still central to the SAE vocabulary, also began to appear in English contexts from 1795-words such as biltong (dried mea'), bredie (a stew), doek (a head scarf), hanepoot (a sweet grape or wine), mealies (maize), and stoep (a verandah).

In 1820 the British settlers came into contact with Dutch-speaking farmers almost immediately upon their arrival, as they were taken by oxwaggon from Algoa Bay to their "locations" (or settlements) in Albany. The landscape, people, rituals, animals, and plants were new and strange to them. 
Words for geographical features, such as kloof, kopje, krantz, poort, rand, and veld, were soon acquired. Everyday life on the frontier particularly required a new vocabulary in certain specialist fields. There was the sub-culture of the "trek-wagon" and the "transport-rider" or carrier-the span (or team) of oxen, the voorloper (or leader of the team), the disselbooms (wagon-poles) and wakis (waggon chest), biltong (dried mea') and beskuit (rusks) for the journey, inspanning (starting) and outspanning (halting), the skof (stage of the journey), and the laager (a defensive ring of wagons). There was farm life, the life of the backveld (from Dutch agterveld) or rural areas - hamels and kapaters (castrated sheep and goats), kraals (animal pens), lands (fields) and camps (paddocks), leading water (irrigating crops), skoffeling (hoeing), breymg or preparing leather, and stock diseases-blood-sickness and gallsickness, lamsiekte, bluetongue, and tulp-poisoning. South African Dutch words were borrowed - in their original form, in translation, or calqued - to describe new phenomena. Marriages between English- and Afrikaans-speakers, and growing bilingualism among English-speakers, particularly in the rural areas, resulted in code-switching and borrowing between English and Afrikaans. Some of the words commonly used in SAE have been altered in grammatical function or sense. For instance $d w a a l$, a verb in Afrikaans (meaning "to go astray, to lose one's way") is most commonly used in SAE in the phrase in a dwaal, meaning "in a daze, distrait".

Many animal and plant names are translations from South African Dutch: bamboo fish, bushbuck, puff-adder, night-adder, redbuck, reedbuck, sea-cow, springbuck; and bitter apple, blackwood, ironwood, milkwood, monkey-rope, stinkwood, sugarbush, and yellowwood. Expressions such as after-chest, after-ox, after-rider, black peril, and fore-house were 19th- and early 20th century translated forms of South African Dutch expressions. Much of the terminology of apartheid came into SAE as a direct translation of the original Afrikaans: such terms include banning order, classify and re-classify, grey area, group area, homeland, immorality act, influx control, job reservation, parallel development, plural development, reference-book, separate development, tricamera and the distinctly un-English other Coloured (an ethnic designation) and own affairs (matters specific to one ethnic group).

English-speakers also appropriated the Afrikaans terminology of the National Party for ironical use, and words such as anderskleunge (one of another colour), betoger (demonstrator), klopjag (police raid), kragdadig (autocratic or heavy-handed), opstoker (agitator), and verkrampte (arch-conservative) were used in the English-language press, and in speech, during the apartheid years.

Many Afrikaans borrowings are standard terms in SAE: for example, bakkie (a light delivery van), boerewors (a spicy sausage), bokmakiene (a common shrike), braai ( barbecue), koeksister (a plaited doughnut, dipped in syrup), laatlammetjie (a child born late in marriage), meerkat (the suricate), middelmannetjie (the ridge down the centre of a narrow farm road), naartjie (a mandarin orange), padkos (food for a journey), rondavel (a circular, single-roomed building with a conical roof), veldskoen (a shoe or ankle-boot of rough leather), and voetsak (said when chasing a dog away).

\subsection{The African Languages}

After the borrowings from Dutch and Afrikaans, the greatest influence upon SAE has been exercised by the Nguni languages, particularly Xhosa and Zulu, as a result of early contact by missionaries and settlers. Words of Xhosa origin such as abakwetha (a Xhosa initiate to manhood), bonsella (a small gift, something extra), indaba (a tribal discussion), tagathi (witchcraft), tokoloshe (a mischievous water-sprite), and umpakati (a tribal councillor) appeared in settler and missionary writings during the 1820s and 1830s. Most of these words entered SAE with reference specifically to Xhosa culture, but over the years many have broadened in sense. The Sotho group of languages, particularly Sesotho and Setswana, have also added to the SAE vocabulary: for example lapa (the forecourt of a homestead, or an open, fenced space in the rest-camp of a game park), morogo (wild spinach), ousie (form of address for a woman), tsessebe (an antelope), and tsetse.

Many well-established vocabulary items have their roots in African languages. Some are assimilated, their prefixes either disappearing or being treated as an integral part of the word, and their Bantu origin often not recognized. Such Words include babalaas (suffering from a hangover), bonsella (a small gift, something extra), cocopan (a heavy ore-container on wheels, an alteration of the Zulu ingqukumbane "stumpy wagon"), dagha (plaster; to plaster, from Xhosa ukudaka), donga (a water-eroded gully), fundi (an expert or buff, probably from Rhodesian, later Zimbabwean, English, from Ndebele umfundi "a disciple, learner" ; or from the identical Xhosa and Zulu), impala (an antelope), induna (a leader), maas (sour milk), mahem (the crowned crane), marula (a tree bearing edible fruit'), пипи (any insect), songololo (a common centipede), tegwaan (the bird Scopus umbretta), tolhe (a young bull or ox), and (old) toppie (an old person). Other borrowings are at a transitional stage, one example, abakwetha, occurring in a range of spellings, disregarding the significance of Nguni singular and plural 
prefixes, and frequently employing the English plural -s (umkwetha(s), amakweta(s), abakwetha(s), kweta(s)).

Many African words have entered English in order to describe cultural or historical phenomena: the Bunga (the Transkei parliament), diretlo (ritual murder), domba (a Venda initiation dance), Fanakalo (a lingua franca developed by mining-companies), imbongi (a praise-singer), inyanga (a herbalist), kgotla (a tribal meeting-place), bogadi or lobola (bride-wealth), Mfecane or Difaqane (the large-scale dispersal of northern Nguni people during the 19th century), pitso (a tribal gathering), sangoma (a diviner).

Expressions in African languages have also been translated into English equivalents" to eat up (to punish an individual or group, especially by confiscating or destroying possessions); great place, great son, great wife (great meaning "pre-eminent" and usually referring to the possessions or family of a chief); monkey's wedding (simultaneous rain and sunshine), to throw the bones (to divine); and to wash (one's) spear (to blood oneself in battle, or to perform a cleansing ceremony after killing in battle).

During the 1980s and 1990s, as the political influence of black South Africans increased, new words of African origin became a part of the broader SAE vocabulary: during the 1980s impimpi (a traitor), maqabane (young ANC activists), mbaqanga (rhythmical township music), spaza (a store run from a township home), stokvel (an informal saving and investment society), and toyi-toyi (a quasi-military dance-step used by marchers and protesters) African terms such as amakhosi (African chiefs collectively) and imbizo (a meeting summoned by a chief) are used in English contexts on radio and television more freely than in the past. In 1995 the national rugby team, the Springboks, were given the African nickname of Amabokoboko, and in 1996 the national soccer team were dubbed Bafana Bafana (Xhosa, "men of men").

\subsection{Other Influential Languages}

Several languages which have had a considerable influence upon the linguistic heritage of South Africa are no longer used in the country, or are spoken only by very small groups.

These words, and others, were specific to Khoikhoi culture when first reported, but have broadened in application to become a part of modern South Africa, occurring in several languages. The Khoikhoi languages exerted most influence on the languages of the Cape Colony, Dutch and Xhosa, as a result of contact during the 17 th and 18th centuries most of the Khoikhoi borrowings now found in SAE were acquired via these two languages. Khoikhoi words in SAE include chacma (a type of baboon), eina (an exclamation of pain), gogga (any insect), kaross (a skin cloak or blanket), kudu and onbi (antelope), quagga (an extinct form of zebra), Xhosa.

Malayo-Javanese languages were introduced into South African society by the so-called "Cape Malays", political exiles and slaves brought to the Cape from Batavia by the Dutch East India Company during the 17th and 18th centuries. These eastern languages had a considerable effect upon Cape Dutch (later Afrikaans), and so too upon English. Commonly encountered borrowings from the Malayo-Javanese languages include bobotie (a curried mince dish), borne (turmeric), ghoen (a large marble), ghomma or goema (a traditional drum), pondok (a rough dwelling), ratiep (a religious sword-ritual performed in a trance-like state), sambal (a side-dish or relish), sjambok (a heavy whip), and sosatie (kebab). As the Cape Malays were Muslim, Arabic words were also introduced by the group, particularly for religious concepts: abdas (the ritual washing of the dead), and kramat (an Islamic shrine) are examples.

Languages of the Indian subcontinent, such as Hindi, Tamil, Urdu, and Gujerati, were introduced by Indian immigrants, both indentured labourers and merchants (the latter known as passenger Indians) from 1860 onwards, particularly in the province now known as KwaZulu-Natal. These languages are spoken by decreasing numbers of (mainly elderly) people, a result of successive generations of education in English. Indian words in SAE include breyani (a curried rice dis'), bunny-chow (a half-loaf of bread, hollowed out and filled with curry), Deepavali ("Diwal", the Festival of Lights), dhal or dholl (lentils), dhunia (coriander), roti (a savoury pancake), and samoosa (a small, triangular pastry filled with curry).

The Jewish community has added some interesting items to the SAE vocabulary, some originating in Yiddish, others in Hebrew. These include kugel (an affluent, spoilt young woman) and bagel (the male equivalent of akugel), gabba (a friend), gattes (a derogatory name for an Afrikaner), gevalt (a rumpus), goniva (a stolen diamond), kitke (the "challah" or Sabbath loaf), and schlenter (a fake diamond).

Apart from the words which were borrowed into SAE from other languages, the South African vocabulary also includes English words which have a particular meaning in SAE. English words with special senses in SAE include advocate (barrister), attorney (solicitor), bioscope (cinema), bond (mortgage), cafe or tearoom (convenience store), cubbyhole (glove-compartment), drift (ford), geyser (water-heater), hostel (either a 
residence for scholars at a boarding-school, or a single-sex dormitory for migrant workers), jersey (any knitted top), just now (in a while), land (a field; a country), motivation (a project proposal, a supporting argument), to recuse (oneself) (to leave a meeting because one has an interest in the subject under discussion), robot (traffic-light), and stand (a plot of land). Subsequent SAE comings include Afrino (a cross between Afrikander and Merino sheep), American kitchen (a fitted kitchen), banana-boy (someone from Natal), bio-cafe (a cinema where films may be watched while food is served), Christmas beetle (a cicada), dumpy (a $340 \mathrm{ml}$ bottle of beer), gem squash (a small, round pumpkin), grey area (an area where people of all races live or work), to have a cadenza (to react hysterically), Old Year's Night (New Year's Eve).

\subsection{South African Middle Class Formation}

Apartheid in South Africa kept Black people from succeeding in the modern industrial world for a long time. They were used largely as a cheap labor force, enjoying the rudiments of education, being kept apart from "White" South Africa. Blacks were segregated from white people from birth to death. They were born in different hospitals, were taught in different schools, worked in different places and finally were buried in different cemeteries. There was practically no middle class mobility for Blacks, there being some differentiation between professionals. Extreme social segregation could not but influence the language. Apartheid in South Africa resulted in at least five main ethnic Englishes, sharply differentiated in accent and syntax. The collapse of apartheid has not destroyed this ethnic variation, and working class varieties of Black, Coloured, Indian and White Englishes can still be discerned (Mesthrie, 2007). Today the working class can feel the benefits of post-apartheid opportunities, as for them racial discrimination has been partly replaced by so called "economic apartheid". It is the middle classes that the most significant changes have occurred. People of colour now have greater opportunities of choosing their places of residence, friends and jobs, and the education and future professions of their children. Recent survey (Seekings \& Natrass, 2005) shows studies that the number of middle class Black households rose by 78\% between 1991 and 1996. The proportion of Blacks in South Africa's middle class has risen from close to zero in the $1980 \mathrm{~s}$ to about $50 \%$. At the beginning of the $21^{\text {st }}$ century the commercial sectors and their advertising wings noticed this dramatic change. Where language is concerned, it seems that English is the language of "distinction" of the new middle class (Bourdieu, 1984). The commercial sector was ready to this change in its consumer base and commissioned a study of "Black diamonds". It aims at young Black people who are expected to shine in terms of educational and work opportunities in the near future, and to have consumer habits similar to the erstwhile white middle class. This is a new status group, likely to form the backbone of a new Black middle class, and possibly a new South African middle class. "The Black diamonds" were sent to schools that were formerly reserved for White students. These are either elite private schools, in which the fees are only affordable by a select number of families, or ex-model $\mathrm{C}$ schools, once restricted to Whites and charging a moderately high fee.

\section{Discussion}

\subsection{Sociolinguistic Awareness of Accelerated Language Change}

Young Black middle class has access to quality education from an early age, which is very important for sociolinguistics. At first Black schoolchildren in the private and model $\mathrm{C}$ schools were in a minority (Da Silva, 2007). Attending such schools, they should speak English as the dominant language of socialisation with the accent common to their peer group (Bangeni \& Kapp, 2007).

Preliminary indications show that young people in the private schools are the most susceptible in language shift. Class differentiation between the new elite students and their township counterparts can be seen at university. Township students at the university labeled other students multis or model C's, using a typical township English abbreviation with denigratory overtones, for "from a multi-racial school" or "from a model C school". The multis for their part rejected township English entirely, seeing it as deficient (De Kadt, 2005). Popular acknowledgement of the phenomenon of identity change can be found in new terms like coconut for the new black children who are "dark on the outside, while on the inside" (Makoe, 2007). This term suggests that the new middle classes have gone beyond the behavioral, cultural and linguistic boundaries of their past background. Some young people are becoming monolingual. What is important that the code choice, repertoire change and language shift is the result of the coconut phenomenon (De Klerk, 2000).

The popular press often focuses on young women as agents of westernisation and language change. An article entitled "Death of the Mother Tongue" (Nicol, 2004) claimed that "Though there are 11 official languages in South Africa, many people are forsaking their mother tongues to speak in an American-English mode considered "cool" by their peers". The article describes the tensions between a young girl's integration into an English-dominant model C school, where the Xhosa language is not taught as a subject, and the more balanced 
bilingualism of her mother, who learnt Xhosa first and then English a generation ago. The older generation frequently disapproves of the Anglicised norms of the younger middle class children. The same newspaper carried an article (Ntshilinga, 2006) citing a university lecturer and cultural expert who says that "smoking starts at social gatherings where women think there is glamour and status associated with it. It is like speaking English. You see them wearing pants with cigarette in hand and they seem to have the notion that they are sophisticated. It seems speaking English and smoking cigarettes go hand in hand with these modern women..." Tensions between language learning and cultural change are evident here.

The degree of integration of the first post-apartheid generation will change in the future, given the country's demographics. Black students were in a minority in the first generation of post-apartheid private and former white public schools. These numbers are increasing. Given the growth of the Black middle class and the slight decline of the White population, the proportions of students that sustained the rise of a prestige White accent among Black pupils will change. Whether the new peer groups would adopt some features of an elite Black identity or whether the prestige varieties have already sufficiently gelled to ensure their own reproduction of essentially White norms will be interesting for future sociolinguistics to monitor (Mesthrie, 2007).

\section{Conclusion}

Many perceive "standard English" to be the English of educated southern England, and do not recognize the existence of a standard form of SAE. There is a conviction that "British English" is the standard against which SAE is judged and found to be wanting. This conviction is a result of many factors, among which are the perception that SAE and slang are synonymous; the belief that the SAE accent is inferior to all other English accents; a lack of understanding of the realities of modern British English; the easy recognition of borrowings into SAE, and the invisible nature of specialized SAE senses of English words; and a lack of knowledge of the age, depth, assimilation, and creativity of the specialist SAE lexicon.

So we may expect that despite the popular support English has among the masses, there is an attitude among the intelligentsia that the dominance of English entrenches present unequal power relations in the country. The future of English within South Africa is not so much a question of what variety of English will emerge, but rather of whether an appropriate learning context can be constructed which enables English to be a language of access and empowerment (Gough, 1996).

\section{References}

Abdulaziz, M. (1972). Triglossia and Swahili-English bilingualism in Tanzania. Sociology of Language, 1, 197-213.

Ansre, G. (1975). Four rationalisations for maintaining the European languages in education in Africa. Paper read at the International Congress of African Studies on the Use of African Languages in Education, Kinshasa. Zaire.

Bamgbose, A. (1976). Mother tongue education: The West African experience. Paris: UNESCO.

Bangeni, B., \& Rochelle, K. (2007). Shifting language attitudes in a linguistically diverse learning environment in South Africa. Journal of Multilingual and Multicultural Development, 28, 253-269.

Bourdieu, P. (1977). The economics of linguistic exchanges. Social Science Information, 16, 645-668.

De Kadt, E. (2005). English language shift and identities: A comparison between "Zulu-dominant" and "multicultural" students on a South African university campus. Southern African Linguistics and Applied Language Studies, 23, 19-37.

Da Silva, A. (2007). South African English: A Sociolinguistic Analysis of an Emerging Variety (Unpublished Ph.D.'s thesis). University of the Witwatersrand.

De Klerk, V. (2000). Language shift in Grahamstown: A case study of selected Xhosa speakers. International Journal of the Sociology of Language, 146, 87-110.

Gough, D. H. (1996). In Silva et al. (Eds.), English in South Africa (pp. XVII-XIX.). Oxford: Oxford University Press.

Khokhlova, I. N. (2007). Characteristics of South African Lexical Component in Modern English and Russian Languages (Candidate dissertation) (p. 270). Petropavlovsk-Kamchatsky: Vitus Bering Kamchatka State University Publishing House.

Khokhlova, I. N. (2011). South African English major influences on South African English vocabulary. In English language teaching: From globalization to cultural diversity (pp. 69-78). Far Eastern State 
University of Humanities Publishing House.

Makoe, P. (2007). Language, discourses and identity construction in a multilingual South African primary school. The English Academy Review: Southern African Journal of English Studies, 24(2), 55-71.

Mesthrie, R. (1992). English in Language Shift: The History, Structure and Sociolinguistics of South African Indian English. Cambridge: Cambridge University Press.

Nicol, M. (2004, February 29). Death of the mother tongue. Sunday Times, 17-18.

Ntshilinga, F. (2006). A cultural taboo goes up in smoke. Sunday Times.

Seekings, J., \& Jill, N. (2005). Class, Race and Inequality in South Africa. New Haven: Yale University Press.

Silva P. M. (1996). Lexicography for South African English. In R. Deklerk (Ed.), English Around The World: Focus on South Africa (p. 435). Amsterdam: John Benjamin.

Silva, P. M., Wendy, D., Dorothea, M., Colin, M., \& Madaleine, W. (1996). A Dictionary of South African English on Historical Principles. Oxford: Oxford University Press.

South Africa's Language Policy: The Facts. (2010). Pretoria: Department of National Education.

Walker, E. A. (1972). A History of South Africa. London: Longman.

\section{Copyrights}

Copyright for this article is retained by the author(s), with first publication rights granted to the journal.

This is an open-access article distributed under the terms and conditions of the Creative Commons Attribution license (http://creativecommons.org/licenses/by/3.0/). 